\title{
"Innovative behavior: the study of intellectual capital effect on creative fashion industry in Bandung, Indonesia"
}

\begin{tabular}{|c|c|}
\hline AUTHORS & $\begin{array}{l}\text { Iwan Sidharta (D https://orcid.org/0000-0002-9276-5910 } \\
\text { R http://www.researcherid.com/rid/P-2254-2019 } \\
\text { M. Sidik Priadana (D https://orcid.org/0000-0001-7098-9705 } \\
\text { Azhar Affandi (D https://orcid.org/0000-0001-7691-021X }\end{array}$ \\
\hline ARTICLE INFO & $\begin{array}{l}\text { Iwan Sidharta, M. Sidik Priadana and Azhar Affandi (2019). Innovative behavior: } \\
\text { the study of intellectual capital effect on creative fashion industry in Bandung, } \\
\text { Indonesia. Problems and Perspectives in Management, 17(4), 404-415. } \\
\text { doi:10.21511/ppm.17(4).2019.33 }\end{array}$ \\
\hline DOI & http://dx.doi.org/10.21511/ppm.17(4).2019.33 \\
\hline RELEASED ON & Saturday, 28 December 2019 \\
\hline RECEIVED ON & Wednesday, 14 August 2019 \\
\hline ACCEPTED ON & Monday, 23 December 2019 \\
\hline LICENSE & $\begin{array}{l}(c) \text { EY } \\
\text { This work is licensed under a Creative Commons Attribution } 4.0 \text { International } \\
\text { License }\end{array}$ \\
\hline JOURNAL & "Problems and Perspectives in Management" \\
\hline ISSN PRINT & $1727-7051$ \\
\hline ISSN ONLINE & $1810-5467$ \\
\hline PUBLISHER & LLC "Consulting Publishing Company "Business Perspectives" \\
\hline =OUNDER & LLC "Consulting Publishing Company "Business Perspectives" \\
\hline
\end{tabular}

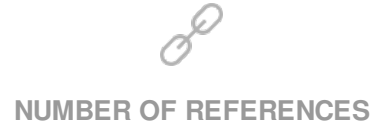

66

\section{NUMBER OF FIGURES}

1
ニニ:-

NUMBER OF TABLES

3

(C) The author(s) 2022. This publication is an open access article. 


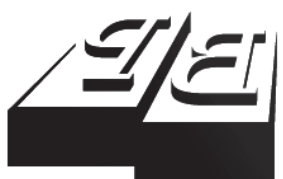

BUSINESS PERSPECTIVES

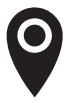

LLC "CPC "Business Perspectives" Hryhorii Skovoroda lane, 10, Sumy, 40022, Ukraine

www.businessperspectives.org

Received on: $14^{\text {th }}$ of August, 2019 Accepted on: 23rd of December, 2019

(C) Iwan Sidharta, M. Sidik Priadana, Azhar Affandi, 2019

Iwan Sidharta, Assistant Professor, Faculty of Management, Department of Management, Sekolah Tinggi Ilmu Ekonomi Pasundan, Bandung, Indonesia.

M. Sidik Priadana, Professor, Doctoral Program in Management, Pasundan University, Indonesia.

Azhar Affandi, Professor, Doctoral Program in Management, Pasundan University, Indonesia.
INNOVATIVE BEHAVIOR:

\section{THE STUDY OF INTELLECTUAL CAPITAL EFFECT ON CREATIVE FASHION INDUSTRY IN BANDUNG, INDONESIA}

\begin{abstract}
Nowadays, the creative industry contributes a lot to the economic growth. Reliable human resources support the organizational success. This study investigates the employees' innovative behavior, which is assumed to be influenced by intellectual capital. This aspect consists of human capital, structural capital, and relational capital. This survey-based research studied the creative industry employees for four months in data collection and four months for analysis and interpretation of data processing results. This study used a quantitative method to answer the proposed hypothesis. The samples were 243 employees of the creative industry in Bandung, Cimahi, Bandung Regency, and West Bandung Regency, Indonesia. For processing the data and testing the hypotheses, the research employed the Partial Least Square-SEM. The results show that there is a compelling effect on human capital, structural capital, and relational capital on innovative behavior. The R-squared value of 0.46 indicates the overall impact. This research suggests some aspects that escalate the innovative behavior. The first aspect is skill enhancement, which leads to the raising of human capital. Next, providing the facilities and infrastructure for internet network connections builds the structural capital. Moreover, offering sources of raw materials needed by employees prompts the relational capital. By carrying out those efforts, the employees' innovative behavior can increase optimally. Research on intellectual capital currently focuses on the performance of the company and dynamic capabilities. Currently, focus on processes of intellectual capital is still in an emerging stage. This study pursues to fulfill the theoretical gap regarding the intellectual capital in which the focus of the research is on innovative behavior in the creative industry.
\end{abstract}

Keywords

JEL Classification human capital, structural capital, relational capital, innovative behavior, creative industry

\section{INTRODUCTION}

The existence of the creative economy due to technological advances is one of the current trends in economic growth in various countries, including Indonesia. The emergence of the creative economy is caused by the rapid advances in media and entertainment. This advancement also instigates the changes in people's lifestyle that is driven by their desire in aesthetics.

Besides, the higher level of competition causes the companies to find the lowest production cost and focus on specific market segments. Competing requires the innovative steps from a creative mindset. Therefore, unusual ways that cannot be imitated by rival companies appear to solve the problems. This competitive situation also requires human resources. They do not only exist but also can make some innovations that lead to competitive advantages. 
The creative economy is a unity of knowledge-based economic activity with dimensions of development and cross-sectoral relations at the macro and micro levels of the economy. The creative economy is an applicative development option for innovative goals. Moreover, it is a response to multidisciplinary policies and interministerial cooperation. The core of the creative economy is the creative industry. The declining economic growth requires a breakthrough to increase it. The economic growth experienced a downward trend from 2014 to 2016. According to the Coordinating Ministry for Economic Affairs (2016), several aspects are the determinants, one of which was the dependence on natural resources. Innovation is necessary to improve the economic growth. Utilizing the creative industry is a way to catch the opportunity that enhances the creative economy.

Creative industry contribution is $7.05 \%$ with moderate growth. This fact shows there is an opportunity to increase the growth and to add value. The contribution of the creative industry is still above the national average GDP. However, preparing creative and innovative human resources is essential to improve the creative sector.

The sectors of the creative industry that have grown and added value are the creative fashion industry, followed by the creative and culinary industry. Meanwhile, performing arts, fine arts, music, design, and publishing have low growth rate and low added value. This fact indicates that boosting the creative fashion industry increases the national economic growth.

The contribution of the growing creative industry in Bandung increased from 2013 to 2015. This condition indicates that the growth of the creative sector contributes to Bandung's economy. The local government commits to increasing the significant contributions. This effort is inseparable from the role of the Mayor of Bandung who tries to turn Bandung into a creative city that can improve the welfare of its citizens. The contribution of the creative economy to the gross regional domestic product (GRDP) of Bandung is relatively good.

Creative industries need creative human resources and innovative behavior (Parkman, Holloway, \& Sebastiao, 2012; Harari, Reaves, \& Viswesvaran, 2016). This condition indicates that policymakers are directing knowledge-intensive workers, such as the creative industry, to increase the competitiveness (M. Cabrita \& C. Cabrita, 2010). There are several multidimensional approaches to the creative industry, namely studies on entrepreneurship, management, and organizational behavior, studies of the environment and social geography, and general. The fundamental aspect of this approach is the problem of creativity and innovation (Kamukama, Ahiauzu, \& Ntayi, 2011). In the field of management, organizational behavior and human resources are related to the needs of organizations to produce something innovative, both products and processes (Alpkan, Bulut, Gunday, Ulusoy, \& Kilic, 2010). Kianto, Andreeva, and Pavlov (2013) state that change and innovation are significant for the success of the organization so that it needs great management for its employees.

Innovative behavior plays a vital role in producing optimal performance (Chen, Chang, \& Lo, 2015). As mentioned by Sharabati, Naji Jawad, and Bontis (2010), innovative behavior is a critical part of innovation for companies. This condition indicates that employees with innovative behavior make a significant contribution to the success of the organization (C. Yu, T. Yu, \& C.C. Yu, 2013; Mura, Lettieri, Spiller, \& Radaelli, 2012). Furthermore, Ramezan (2011) state that innovation is a dynamic process flowing all the time and brings many potential benefits for the organization. Petty and Guthrie (2000) believe having good ideas is insufficient; turning ideas into intangible products or services is a further essential step. Thus, increasing the implementation of the idea is necessary so that the employees' innovative behavior can be optimized. Some efforts made by the employees in an organization need to be measured objectively to determine the extent of its contribution to the achievement of organizational goals. (Carmeli, Meitar, \& Weisberg, 2006) The measurement results are indicators for the success or failure of employees in an organization in carrying out their duties. Innovative behavior influences the employee performance (De Jong \& Den Hartog, 2010). 
Research on intellectual capital currently focuses on the company's performance and dynamic capabilities, while there are still a few studies that focus on employee behavior. As research conducted by Maditinos, Chatzoudes, Tsairidis, and Theriou (2011), Clarke, Seng, and Whiting (2011), Martínde-Castro, Delgado-Verde, López-Sáez, and Navas-López (2011), Sydler, Haefliger, and Pruksa (2014), the study focuses on company's performance. Some researches focus on dynamic capabilities such as Kamukama et al. (2011), Hsu and Wang (2012), and Kianto et al. (2013). Achieving the organizational goals cannot be separated from the resources that are used or run by employees who play an active role as the man of action to achieve the organizational goals. This research attempts to find the gap of intellectual capital research that focuses on the innovative behavior of employees. The study conducted by Shih, Chang, and Lin (2010) shows that knowledge creation increases the intellectual capital in the bank industry. Furthermore, the increase in intellectual capital will increase the innovative behavior. Guthrie, Ricceri, and Dumay (2012) confirm the focus on processes of intellectual capital is still in an emerging stage characterized by measurement of intellectual capital in organizations so that they can explore how the intellectual capital implications in organizations such as the employee behavior. Furthermore, Dumay and Garanina (2013) suggest that intellectual capital research focuses on how processes to produce competitive products and services are related to individual behavior within the organization. This study attempts to fill the theoretical gap regarding intellectual capital, as suggested by Guthrie et al. (2012) and Dumay (2016), in which the focus of research is on innovative behavior in the creative industry. Previous studies by Kamukama et al. (2011), Hsu and Wang (2012), and Kianto et al. (2013), Shih, Chang, and Lin (2010) show that every aspect begins from the dynamic process of individual behavior in the organization. This study bridges the effect of intellectual capital that leads to employees' innovative behavior in the creative fashion industry.

Based on the background of the problem, the critical role, and previous research, this study was conducted to determine the impact of human capital, structural capital, and relational capital on innovative behavior in the creative fashion industry in Bandung. The study provides new theoretical frameworks in the development of analytical models for human resource management, especially innovative behavior concerning intellectual capital in the creative fashion industry.

\section{LITERATURE REVIEW}

Human capital contributes to innovative behavior. Intangible asset of the organization is human capital. This asset is essential since human capital enables the organization to increase its competitiveness (Maditinos, Chatzoudes, Tsairidis, \& Theriou, 2011). Alpkan, Bulut, Gunday, Ulusoy, and Kilic (2010) show that currently, we face a new economic paradigm that describes speed, innovation, short term cycle, quality, and customer satisfaction. It is an essential part of intangible assets such as brand recognition, knowledge, innovation, and especially human capital (Wang \& Chen, 2013; Díez, Ochoa, Prieto, \& Santidrián, 2010). Hollenbeck and Jamieson (2015) state that human capital is an intellectual asset and that the management of human resources within the organization can encourage it. Carson, Ranzijn, Winefield, and Marsden (2004) believe that the challenges of organizational behavior regarding individuals and value to human capital and teamwork can be obtained through knowledge, experience, and commitment as valuable human assets.

Human capital can improve structural capital by using the available information technology for the organization. Benevene and Cortini (2010) state there is a synergy between structural capital and human capital, in which the development of human capital can increase structural capital. However, their research shows that there is no management attention in improving human capital. It is seen from the provision of training and adequate structural capital support to senior Italian NPOs managers. Ramezan (2011) suggests that structural capital in organizations can be a tool to support human capital in carrying out their duties effectively. Relational capital relates to the wants and needs of consumers in connection with the superior quality of products or services. The driver of the organization's operations 
is human capital. It comes with the commitment to produce a high-quality product along with the knowledge and ability to make it happen. Dalziel, Gentry, and Bowerman (2011) prove that there is an interaction between human capital and relational capital in increasing desire to spend $\mathrm{R} \& \mathrm{D}$ in US biotechnology and pharmaceutical industries. This condition indicates that the presence of optimal human capital improves the structural capital and relational capital. Besides, structural capital factors are one of the essential aspects of innovative behavior. Though the information system is available, the unsupported technology and the access to information has not been well prepared by the company.

H1: There is an influence of human capital on structural capital and relational capital.

Benevene and Cortini (2010) state that structural capital has two considerable aspects, namely the development of semi-permanent knowledge that grows in a job and a device that develops the body of knowledge with relevant expertise by two components form structural capital, such as facilities and infrastructure concerning the utilization of employees knowledge. The role of employee structural capital is inseparable from the function in accelerating the dissemination of knowledge, growing the experience, shortening the time distance, and making people more productive (Carson, Ranzijn, Winefield, \& Marsden, 2004; Swart \& Kinnie, 2010). Kang, Snell, and Swart (2012) believe the role of increasing structural capital in expanding the company's ability to increase the produced added value. A question as that asks how to provide both explicit and accurate information enables to find the appropriate method to increase structural capital. Thus, it can be assumed that structural capital can improve the employees' innovative behavior.

\section{H2: There is an influence of structural capital on the employees' innovative behavior.}

The last factor that allegedly influences innovative behavior is relational capital. Customer satisfaction can be obtained if employees provide the best quality. It is by establishing harmonious relationships with suppliers to know the availability of raw material and to produce innovative and creative ideas in order to fulfill customer needs. Serenko, Bontis, Booker, Sadeddin, and Hardie (2010) believe relational capital is one of the foundations of organizational effectiveness as an intangible asset. The understanding of relational capital, along with the support of innovative behavior, produces longterm benefits with customers. As stated by Crema and Verbano (2016) and Mossholder, Richardson, and Settoon (2011), it is essential for the employees to understand the customers and be aware of the competitors in more creative and innovative ways to improve the performance and competitiveness.

\section{H3: There is the impact of the relational capital towards innovative behavior of employees.}

The presence of intellectual capital, such as human capital, structural capital, and relational capital, enhances creative behavior. Human capital initiates the added value that workers can give to organizations. Human capital is a distinguishing factor and the actual basis of an organization's competitive advantage. The conceptualizing employees have a set of skills to lease to their organizations. Employees' knowledge and skills from education and training, including skills from their experience, produce the availability of specific productive capital (Becker, 1994). The above statements show the critical role of human resources in producing the innovation as a contribution to enhancing the organizational competitiveness. The optimal management of human resources creates high performance. Santos-Rodrigues, Dorrego, and Jardon (2010) state that employee creative initiatives will increase the better ideas, decisions, quality, and productivity. That excellent management improves the individual performance, which in turn enhances the organizational performance. The essential element of an organization's intangible assets is human capital. All these intangible assets, especially the expertise, imagination, and creativity of employees, are significant for the organizational success (Luthans \& Youssef, 2004). Creativity, expertise, and imagination shape the innovative behavior. The importance of human capital assets causes the need for measuring the value of intangible assets (Sidharta \& Affandi, 2016). Measurement is an appliance to assess the use and effectiveness of human capital. A research conducted by Dumay and Garanina (2013) on the Chief Executive Officer (CEO) of 27 public compa- 
nies in Australia proved that human capital has a profound influence on innovative behavior.

Besides human capital and structural capital, relational capital also improves the innovative behavior. Relational capital deals with the form of learning about consumers and how to gain customer trust. The learning process about the wants and needs of customers requires a strong effort from the employees to fulfill the customer desires. Suraj and Bontis (2012) argue that an established customer base, positive reputation, ongoing relationships, and goodwill built by the enterprise are related to fostering the stable relations with their customers. The process runs well if it forms innovative behavior in producing a method that is faster and better than before.

Innovative behavior actualizes the learning process to gain the customer trust (Santos-Rodrigues, Dorrego, \& Jardon, 2010). The existence of relational capital can support the innovative behavior. Confirmed by De Jong and Den Hartog (2010), innovative creativity and behavior solve the problems faced by employees. A research conducted by Prajogo and Ahmed (2006) prove that relational capital has a significant effect on innovative behavior. Furthermore, a meta-analysis study by Mention (2012) concludes that relational capital has a positive influence on innovative behavior.

H4: There is an influence of human capital, structural capital, and relational capital on the employees' innovative behavior.

\section{METHODS}

This study utilizes the survey method to determine the phenomenon of research variables which tested the established hypotheses to assess the effect of human capital, structural capital, and relational capital towards employees' innovative behavior in the creative fashion industry in Bandung.

Operational analysis of research variables is human capital, with some indicators developed by Bontis, Keow, and Richardson (2000) and Ulrich (1998), which consist of knowledge, skills, abilities, and commitment. Structural capital indicators are measured by using four indicators devel- oped by Sullivan (2000), such as technology, information systems, procedures, and infrastructure. Relational capital is measured by using four indicators developed by Sveiby (1998), namely customer relations, supplier relations, reputation, and market reach. Indicators of innovative behavior are measured by idea generation, idea promotion, and idea implementation developed by Scott and Bruce (1994) and Janssen (2000).

In this study, the population is employees in the creative fashion industry, which are Bandung, Cimahi, Bandung, and West Bandung Regency. This study uses the Slovin formula to take samples from the population in Bandung, Cimahi, Bandung Regency, and West Bandung Regency. This study had some steps to get secondary data. This study surveyed the Bandung Government, Cimahi Government, Bandung Tourism Office, Government of West Bandung Regency. Furthermore, this study determined the respondents. The chosen enterprise must have more than ten employees. Every region has four coordinators to collect the data.

By knowing the population $(N=622)$ as many as the study population and with a level of precision $\left(d^{2}\right)$ set at $\% 5$, the samples used in this study were 243 people. The sample was taken by using Proportional Random Sampling. This study uses the component of the Partial Least SquareCovariant Base Structural Equation Modeling (CB-SEM) in testing the hypotheses.

In processing data, this study uses the WarpPLS 5 tool with a second-order approach. The Gof criterion refers to Tanenhaus's, while the requirements for validity and constructs reality refer to the constructed value of validity $>0.5$ and reliability $>0.7$. (Fornell \& Larcker, 1981) Table 1 shows the validity and reliability results.

The results show that the research indicators fulfill the criteria. Determination of the fit model is according to the results of quality indices where Average Path Coefficient $($ APC $)=0.425, P<0.001$ and Average $R$-squared (ARS) $=0.453, P<0.001$, and Average Adjusted $R$-squared (AARS) $=0.451$, $P<0.001$. Collinearity testing shows Average Block VIF $($ AVIF $)=1.691$, with acceptable criteria if $<=5$. The path analysis model refers to Tenenhaus 
Table 1. Result of validity and reliability testing

\begin{tabular}{|c|c|c|c|c|}
\hline Variables & Indicators & AVE & Cronbach's alpha & Composite reliability \\
\hline \multirow{5}{*}{ Human capital } & Knowledge & 0.597 & 0.742 & 0.830 \\
\hline & Skills & 0.599 & 0.829 & 0.873 \\
\hline & Abilities & 0.540 & 0.832 & 0.870 \\
\hline & Commitment & 0.611 & 0.772 & 0.803 \\
\hline & Human capital & 0.736 & 0.880 & 0.918 \\
\hline \multirow{5}{*}{ Structural capital } & Technology & 0.551 & 0.746 & 0.858 \\
\hline & Information systems & 0.597 & 0.797 & 0.873 \\
\hline & Procedures & 0.543 & 0.743 & 0.829 \\
\hline & Infrastructure & 0.596 & 0.765 & 0.865 \\
\hline & Structural capital & 0.735 & 0.880 & 0.917 \\
\hline \multirow{5}{*}{ Relational capital } & Customer relations & 0.585 & 0.855 & 0.893 \\
\hline & Supplier relations & 0.742 & 0.753 & 0.852 \\
\hline & Reputation & 0.656 & 0.737 & 0.851 \\
\hline & Market reach & 0.622 & 0.743 & 0.806 \\
\hline & Relational capital & 0.534 & 0.708 & 0.820 \\
\hline \multirow{4}{*}{ Innovative behavior } & Idea generation & 0.566 & 0.807 & 0.867 \\
\hline & Idea promotion & 0.557 & 0.800 & 0.862 \\
\hline & Idea implementation & 0.523 & 0.770 & 0.845 \\
\hline & Innovative behavior & 0.734 & 0.818 & 0.892 \\
\hline
\end{tabular}

$\mathrm{GoF}(\mathrm{GoF})=0.501$, with criteria small $>=0.1$, medium $>=0.25$, large $>=0.36$ (Kock, 2012). Based on the criteria, it can be concluded that the results are good enough to explain the research model. As seen in the results of TenenhausGoF $(\mathrm{GoF})=0.501$ with large criteria.

\section{RESULT AND DISCUSSION}

The questionnaires were distributed to employees of the creative fashion industry. The samples are 243 people from 113 creative industry enterprises in the fashion sector in Bandung, Cimahi, Bandung Regency, and West Bandung Regency. Table 2 shows the data on the characteristics of respondents.

Table 2. Respondents' characteristics

\begin{tabular}{|c|c|c|}
\hline Description & Category & $\%$ \\
\hline \multirow{2}{*}{ Gender } & Male & 53.86 \\
\hline & Female & 46.14 \\
\hline \multirow{3}{*}{ Working period } & $3<$ years & 44.05 \\
\hline & $4-5$ years & 35.21 \\
\hline & $>6$ years & 20.74 \\
\hline \multirow{3}{*}{ Education level } & High school & 34.89 \\
\hline & Diploma & 38.10 \\
\hline & Graduate & 27.01 \\
\hline
\end{tabular}

When viewing gender as a part of respondents' characteristics, it is found that male is dominant in the creative industry. The period of work is dominated by employees who work under three years. This condition is caused by the development of creative industries that increasingly show an upward trend, which requires new employees. The level of education is dominated by employees with a diploma degree. This finding indicates that employees of the creative fashion industry need more skills than conceptual abilities. Furthermore, Figure 1 shows the results of the calculation procedure by using CB SEM-PLS.

Figure 1 shows the result of calculations by using WarpPLS 5.0. Conclusions can be given on the proposed hypotheses, as shown in Table 3.

The calculation results show that $H 1$ is significant, which means that there is a significant influence of human capital on structural capital and relational capital. For companies that are engaged in knowledge-based sectors, human capital is an essential resource (Parkman, Holloway, \& Sebastiao, 2012). One of the foundations to compete is human capital, which can produce sources of innovation and companies innovative strategies based on employees' tacit knowledge. It is on the same path with the knowledge-based approach, which is a new extension of the enterprise-based resources, Resource-Based View (RBV), and provides strong theoretical support for intellectual capital. This theory forms the basis for building the involvement of human capital in the company's rou- 
Table 3. Result of path coefficients and hypotheses testing

\begin{tabular}{|c|c|c|c|c|}
\hline Variables & Path coefficients & $p$-value & Sig. value & Description \\
\hline Human capital $\rightarrow$ Structural capital & 0.563 & 0.000 & 0.036 & Accept \\
\hline Human capital $\rightarrow$ Relational capital & 0.623 & 0.000 & 0.006 & Accept \\
\hline Human capital $\rightarrow$ Innovative behavior & 0.505 & 0.000 & 0.000 & Accept \\
\hline Structural capital $\rightarrow$ Innovative behavior & 0.268 & 0.000 & 0.000 & Accept \\
\hline Relational capital $\rightarrow$ Innovative behavior & 0.168 & 0.000 & & Accept \\
\hline \multicolumn{5}{|c|}{ Structural capital } \\
\hline$R$-squared & 0.316 & & & \\
\hline Adjusted $R$-squared & 0.314 & & & \\
\hline \multicolumn{5}{|c|}{ Relational capital } \\
\hline$R$-squared & 0.388 & & & \\
\hline Adjusted $R$-squared & 0.385 & & & \\
\hline \multicolumn{5}{|c|}{ Innovative behavior } \\
\hline$R$-squared & 0.655 & & & \\
\hline Adjusted $R$-squared & 0.652 & & & \\
\hline
\end{tabular}

tine activities by increasing employee involvement in the formulation of the company's operational and long-term goals. In a knowledge-based view, companies develop new knowledge that is important for competitive advantage and unique value creation. Research conducted by $\mathrm{Wu}$, Chang, and Chen (2008) proves that there is a significant impact on innovative behavior. The result is in line with Prajogo and Ahmed (2006) who tested innovative stimulation, which was influenced by the employees' knowledge. Research by $\mathrm{Wu}$, Lin, and Hsu (2007) and Cingoz and Akdogan (2011) also prove that human capital has a significant effect on innovative behavior.

H2: There is evidence that shows the influence of structural capital on employees' innovative behav- ior. The result shows that the presence of structural capital improves the employees' innovative behavior. Youndt, Subramaniam, and Snell (2004) state that there is a strong relationship between structural and value creation. It can be strengthened by creating lateral relationships such as work units and teams that facilitate the flow of information between independent departments, thereby reducing or eliminating the high-cost, the up and down information flows (Dong \& Gao, 2012). Through hierarchical channels. Concerning organizational design, the development of capital requires the development of organizations that function through parallel processes across functional boundaries in multi-layered structures that considered portfolios of dynamic processes. This process consists of interdisciplinary networks and project teams as

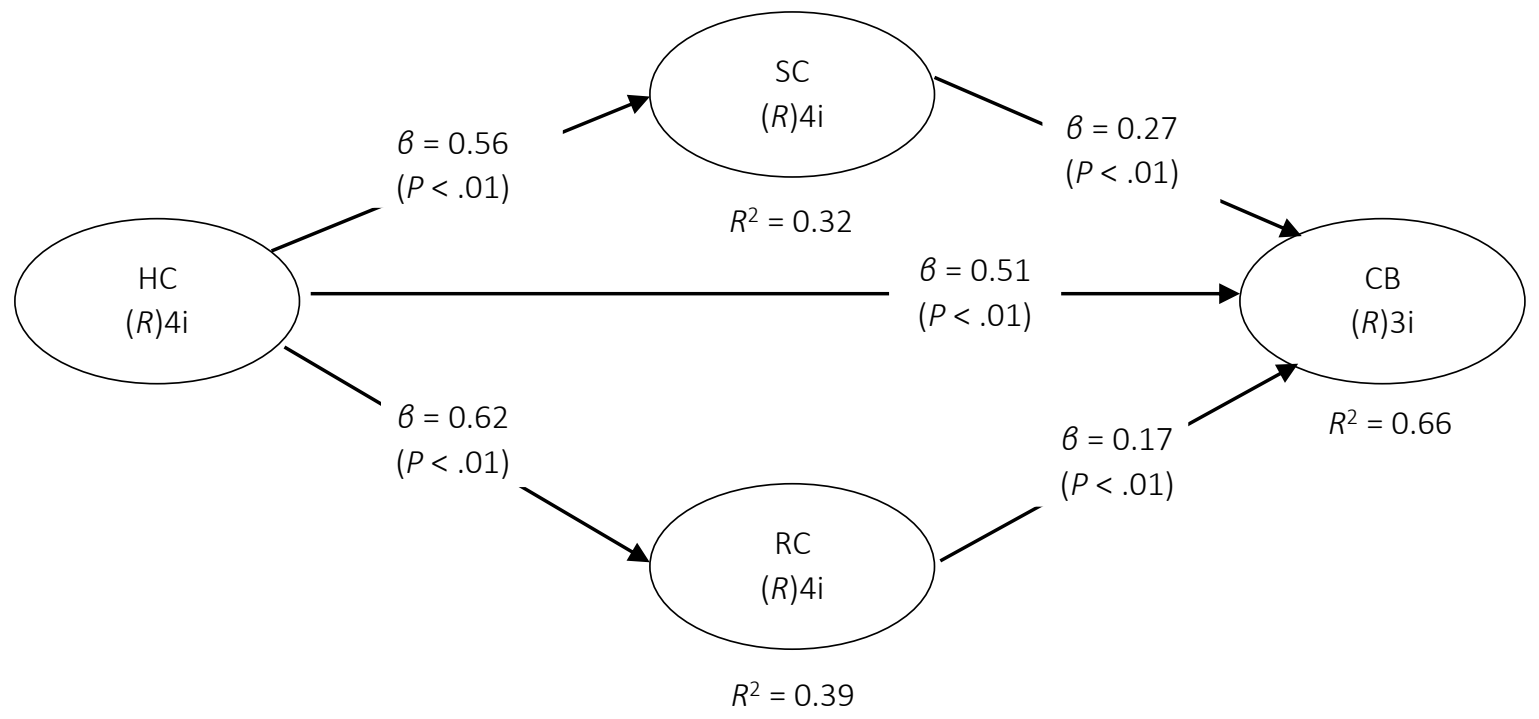

Figure 1. Results of calculation of research models 
a way of developing, sharing, and disseminating knowledge (Chen, Wang, \& Sun, 2012).

Structural capital is knowledge that can be owned by organizations, not workers or individuals. Swart (2006) states structural capital can be described as a knowledge that is planted or stored with the assistance of information technology in a database that is easily accessed and disseminated. It is including explicit knowledge - an ability that is owned by the company in utilizing human capital so that it can produce added value for the company. To achieve the organizational goals, a facility is needed to support the employees' ability. Therefore, it creates a particular behavior that encourages the success of achieving the organizational goals (M. Cabrita \& C. Cabrita, 2010). Steward (1994) states that structural capital plays an essential role in producing something that is valuable (innovative). This fact suggests that the presence of structural capital strengthens the employees' innovative behavior in delivering optimal performance. A research conducted in Slovenia and Croatia by Omerzel and Jurdana (2016) proves that structural capital has an intense effect on innovative behavior. Similarly, studies conducted by Carmeli and Spreitzer, 2009; and Ghorbani, Mofarredi, and Bashiriyan (2012) prove that structural capital has an enormous effect on innovative behavior.

H3 is proved to be significant. There is a relational capital effect on employees' innovative behavior. These findings indicate that the higher relational capital, the more innovative employees' behavior. The learning process about the wants and needs of customers requires a strong effort from the employees to fulfill customer needs. It is in line with Scarborough and Cornwall (2015, p. 135) statement about establishing the customer base, positive reputation, sustainable relation, and goodwill with its customers. Hsu and Wang (2012) state that structural capital, such as operations, procedures, and processes of knowledge management, lead to organizations' value creation activities such as innovative behavior. The progress runs well if it forms innovative behavior in producing a faster and better process. The role of the learning process to gain customer trust can be actualized by innovative behavior (Harari, Reaves, \& Viswesvaran, 2016). Research conducted by Smith,
Collins, and Clark (2005) and Wu, Lin, and Hsu (2007) prove that relational capital influences the innovative behavior.

The last hypothesis (H4) has a huge influence on human capital, structural capital, and relational capital on employees' innovative behavior. The finding shows that increasing human capital, structural capital, and relational capital will also increase the employees' innovative behavior. Human capital initiates added value that employees can give to organizations. Human capital is a distinguishing factor and the actual basis of an organization's competitive advantage. Human capital conceptualizes that employees have a set of skills that can be leased to their organizations (Sveiby, 1997). Employees' knowledge and skills from education and training, including skills that come from experience, produce certain productive capital stocks. Human capital is an essential element of an organization's intangible assets. All these intangible assets, especially the expertise, imagination, and employees' creativity, are significant for the organization's success (Harari, Reaves, \& Viswesvaran, 2016). The creativity, expertise, and imagination shape the innovative behavior. The importance of human capital assets causes the importance of measuring the value of intangible assets. The purpose of measurement is to assess how well the use and effectiveness of human capital. According to M. Cabrita and C. Cabrita (2010), organizations provide the essential continuity needed by employees so that they can increase their ability to develop and learn to achieve their goals. Stewart (1994) emphasizes that structural capital is the company's ability to share and transmit knowledge about company activities that are connected to the creation, sharing, shipping, and dissemination of knowledge and capabilities. At the same time, it is a real company's investment to grow in the future through research and development. Relational capital is related to the form of learning about consumers and how to get customer trust (Hormiga, BatistaCanino, \& Sánchez-Medina, 2011). The results of this study prove that relational capital can support the innovative behavior. Research conducted by Pundt, Martins, and Nerdinger (2010) and Santos-Rodrigues et al. (2010) demonstrates that human capital has a significant effect on innovative behavior. 


\section{CONCLUSION}

The creative economy is one of the applicative development options for innovative goals as contributors to economic growth. Definitely, supporting creative industries contributes to the growth of economic. Increasing the industry's existing human resources, which is inseparable from the role of human capital, structural capital, and relational capital in enhancing its innovative behavior is a way to improve the performance of the creative industry. According to the results of the study, human capital, structural capital, and relational capital have intense effects on employees' innovative behavior. To enhance the innovative behavior, the creative industry players increase their human capital through skill enhancement, the improvement of structural capital by providing facilities and infrastructure for internet network connections, and the development of relational capital by offering the sources of raw materials needed by employees. Therefore, employees' innovative behavior can increase optimally.

The results of the study contribute to the study of intellectual capital in enhancing employees' innovative behavior in the creative fashion industry. This research still has several weaknesses in which the population is only in the creative fashion industry. Future studies can use populations in the other sectors of the creative industry to obtain more comprehensive research models.

\section{REFERENCES}

1. Alpkan, L., Bulut, C., Gunday, G., Ulusoy, G., \& Kilic, K. (2010). Organizational support for intrapreneurship and its interaction with human capital to enhance innovative performance. Management Decision, 48(5), 732-755. https://doi. org/10.1108/00251741011043902

2. Becker, G. S. (1994). Human capital revisited. In Human Capital: A Theoretical and Empirical Analysis with Special Reference to Education (3rd ed.) (pp. 15-28). The university of Chicago press. Retrieved from https://www.nber.org/chapters/ c11229

3. Benevene, P., \& Cortini, M. (2010). Interaction between structural capital and human capital in Italian NPOs: Leadership, organizational culture and human resource management. Journal of Intellectual Capital, 11(2), 123-139. https://doi. org/10.1108/14691931011039642

4. Bontis, N., Keow, C. C. W., \& Richardson, S. (2000). Intellectual capital and business performance in Malaysian industries. Journal of Intellectual Capital, 1(1), 85-100. https://doi. org/10.1108/14691930010324188
5. Cabrita, M. R., \& Cabrita, C. (2010, March). The role of creative industries in stimulating intellectual capital in cities and regions. In Proceedings of the European Conference on Intellectual Capital (pp. 171179). Retrieved from https:// www.researchgate.net/ publication/277577452_The Role_of_Creative_Industries in_Stimulating_Intellectual_Capital_in_Cities_and_Regions

6. Carmeli, A., \& Spreitzer, G. M. (2009). Trust, connectivity, and thriving: Implications for innovative behaviors at work. The Journal of Creative Behavior, 43(3), 169-191. https://doi. org/10.1002/j.2162-6057.2009. tb01313.x

7. Carmeli, A., Meitar, R., \& Weisberg, J. (2006). Self-leadership skills and innovative behavior at work. International Journal of Manpower, 27(1), 75-90. Retrieved from https://pdfs.semanticscholar. org/6779/74001634b41295789845 3525bfd5f93dec27.pdf

8. Carson, E., Ranzijn, R., Winefield, A., \& Marsden, H. (2004). Intellectual capital: Mapping employee and work group attributes. Journal of Intellectual Capital, 5(3), 443-463. Retrieved from https://www.researchgate. net/publication/235288981_Intellectual_Capital_Mapping_Employee_and_Work_Group_Attributes

9. Chen, Y. C. M., Wang, S. Y., \& Sun, V. (2012). Intellectual capital and organizational commitment: Evidence from cultural creative industries in Taiwan. Personnel Review, 41(3), 321-339. Retrieved from https://www.researchgate. net/publication/242342563_Intellectual_capital_and_organizational_commitment_Evidence_ from_cultural_creative_industries_in_Taiwan

10. Chen, M. H., Chang, Y. Y., \& Lo, Y. H. (2015). Creativity cognitive style, conflict, and career success for creative entrepreneurs. Journal of Business Research, 68(4), 906910. https://doi.org/10.1016/j. jbusres.2014.11.050

11. Cingöz, A., \& Akdoğan, A. A. (2011). An empirical examination of performance and image outcome expectation as determinants of innovative behavior in the workplace. Procedia-Social and Behavioral Sciences, 24, 847-853. https://doi. org/10.1016/j.sbspro.2011.09.099

12. Clarke, M., Seng, D., \& Whiting, R. H. (2011). Intellectual capital 
and firm performance in Australia. Journal of Intellectual Capital, 12(4), 505-530. https://doi. org/10.1108/14691931111181706

13. Coordinating Ministry for Economic Affairs. (2016). Ekonomi Kreatif: Kekuatan Baru Indonesia Menuju 2025. Jakarta: Coordinating Ministry for Economic Affairs.

14. Crema, M., \& Verbano, C. (2016). Managing Intellectual Capital in Italian Manufacturing SMEs. Creativity and Innovation Management, 25(3), 408421. https://doi.org/10.1111/ caim. 12074

15. Dalziel, T., Gentry, R. J., \& Bowerman, M. (2011). An integrated agency - resource dependence view of the influence of directors' human and relational capital on firms' R\&D spending. Journal of Management Studies, 48(6), 1217-1242. Retrieved from https://www.researchgate.net/ publication/227375532_An_Integrated_Agency-Resource_Dependence_View_of_the_Influence_of Directors'_Human_and_Relational_Capital_on_Firms'_RD_Spending

16. De Jong, J., \& Den Hartog, D. (2010). Measuring innovative work behaviour. Creativity and innovation Management, 19(1), 23-36. https://doi.org/10.1111/ j.1467-8691.2010.00547.x

17. Díez, M. J., Ochoa, M. L., Prieto, M. B., \& Santidrián, A. (2010). Intellectual capital and value creation in Spanish firms. Journal of intellectual capital, 11(3), 348-367. https://doi. org/10.1108/14691931011064581

18. Dong, Q., \& Gao, C. (2012). Knowledge engineering, intellectual capital of creative industry park based on multiobjective decision-making and entropy methods. Systems Engineering Procedia, 3, 326332. https://doi.org/10.1016/j. sepro.2011.11.037

19. Dumay, J. (2016). A critical reflection on the future of intellectual capital: from reporting to disclosure. Journal of Intellectual Capital, 17(1), 168-184.
https://doi.org/10.1108/JIC-082015-0072

20. Dumay, J., \& Garanina, T. (2013). Intellectual capital research: a critical examination of the third stage. Journal of Intellectual Capital, 14(1), 10-25. Retrieved from https://www.researchgate. net/publication/235310641_Intellectual_capital_research_A_critical_examination_of_the_third_ stage

21. Fornell, C., \& Larcker, D. F. (1981). Evaluating structural equation models with unobservable variables and measurement error. Journal of Marketing Research, 3950. Retrieved from https://www. jstor.org/stable/3151312?seq=1

22. Ghorbani, M., Mofaredi, B., \& Bashiriyan, S. (2012). Study of the relationship between intellectual capital management and organizational innovation in the banks. African Journal of Business Management, 6(15), 5208-5217. Retrieved from https://www.researchgate.net/ publication/269673259_Study_of_ the_relationship_between_intellectual_capital_management_and_ organizational_innovation_in_ the banks

23. Guthrie, J., Ricceri, F., \& Dumay, J. (2012). Reflections and projections: a decade of intellectual capital accounting research. The British Accounting Review, 44(2), 68-82. https://doi. org/10.1016/j.bar.2012.03.004

24. Harari, M. B., Reaves, A. C., \& Viswesvaran, C. (2016). Creative and innovative performance: A meta-analysis of relationships with task, citizenship, and counterproductive job performance dimensions. European Journal of Work and Organizational Psychology, 25(4), 495-511. Retrieved from https://www.researchgate.net/ publication/291418033_Creative_and_innovative_ performance_a_meta-analysis_of_ relationships_with_task_citizenship_and_counterproductive_job_ performance_dimensions

25. Hollenbeck, J. R., \& Jamieson, B. B. (2015). Human capital, social capital, and social network analysis: Implications for strategic human resource management. Academy of Management Perspectives, 29(3), 370-385. Retrieved from https://www.researchgate. net/publication/281982213_Human_Capital_Social_Capital_and_ Social_Network_AnalysisImplications_for_Strategic_Human_Resource_Management

26. Hormiga, E., Batista-Canino, R. M., \& Sánchez-Medina, A. (2011). The impact of relational capital on the success of new business start-ups. Journal of Small Business Management, 49(4), 617-638. https://doi.org/10.1111/j.1540627X.2011.00339.x

27. Hsu, L. C., \& Wang, C. H. (2012). Clarifying the effect of intellectual capital on performance: the mediating role of dynamic capability. British Journal of Management, 23(2), 179-205. Retrieved from https:// www.researchgate.net/publication/229881153_Clarifying_the_ Effect_of_Intellectual_Capital_on_Performance_The_Mediating_Role_of_Dynamic_Capability

28. Janssen, O. (2000). Job demands, perceptions of effort-reward fairness and innovative work behaviour. Journal of Occupational and Organizational Psychology, 73(3), 287-302. https://doi. org/10.1348/096317900167038

29. Kamukama, N., Ahiauzu, A., \& Ntayi, J. M. (2011). Competitive advantage: mediator of intellectual capital and performance. Journal of Intellectual Capital, 12(1), 152-164. https://doi. org/10.1108/14691931111097953

30. Kang, S. C., Snell, S. A., \& Swart, J. (2012). Options-based HRM, intellectual capital, and exploratory and exploitative learning in law firms' practice groups. Human Resource Management, 51(4), 461485. https://doi.org/10.1002/ hrm.21484

31. Kianto, A., Andreeva, T., \& Pavlov, Y. (2013). The impact of intellectual capital management on company competitiveness and financial performance. Knowledge 
Management Research \& Practice, 11(2), 112-122. Retrieved from https://link.springer.com/article/10.1057/kmrp.2013.9

32. Kock, N. (2012). WarpPLS 3.0 user manual. Laredo, TX: ScriptWarp Systems. Retrieved from https:// www.researchgate.net/publication/265219569_WarpPLS_30_ User_Manual

33. Luthans, F., \& Youssef, C. M. (2004). Human, social, and now positive psychological capital management: Investing in people for competitive advantage. Organizational Dynamics, 33(2), 143-160. https://doi.org/10.1016/j. orgdyn.2004.01.003

34. Maditinos, D., Chatzoudes, D., Tsairidis, C., \& Theriou, G. (2011). The impact of intellectual capital on firms' market value and financial performance. Journal of Intellectual Capital, 12(1), 132-151. Retrieved from https://www.researchgate.net/ publication/235273097_The_impact_of_intellectual_capital_on_ firms'market_value_and_financial_performance

35. Martín-de-Castro, G., DelgadoVerde, M., López-Sáez, P., \& Navas-López, J. E. (2011). Towards 'an intellectual capital-based view of the firm': origins and nature. Journal of Business Ethics, 98(4), 649-662. Retrieved from https:// link.springer.com/article/10.1007/ s10551-010-0644-5

36. Mention, A. L. (2012). Intellectual capital, innovation and performance: A systematic review of the literature. Business and Economic Research, 2(1), 1-37. https://doi.org/10.5296/ber. v2i1.1937

37. Mossholder, K. W., Richardson, H. A., \& Settoon, R. P. (2011). Human resource systems and helping in organizations: A relational perspective. Academy of Management Review, 36(1), 33-52. Retrieved from https:// journals.aom.org/doi/abs/10.5465/ amr.2009.0402?journalCode $=\mathrm{amr}$

38. Mura, M., Lettieri, E., Spiller, N., \& Radaelli, G. (2012). Intellectual capital and innovative work behaviour: Opening the black box. International Journal of Engineering Business Management, 4, 4-39. https://doi. org/10.5772\%2F54976

39. Omerzel, D. G., \& Jurdana, D. S. (2016). The influence of intellectual capital on innovativeness and growth in tourism SMEs: empirical evidence from Slovenia and Croatia. Economic ResearchEkonomska Istraživanja, 29(1), 1075-1090. Retrieved from https:// www.researchgate.net/publication/312278868_The_influence_ of_intellectual_capital_on_innovativeness_and_growth_in_tourism_SMEs_Empirical_evidence_ from_Slovenia_and_Croatia

40. Parkman, I. D., Holloway, S. S., \& Sebastiao, H. (2012) Creative industries: aligning entrepreneurial orientation and innovation capacity. Journal of Research in Marketing and Entrepreneurship, 14(1), 95114. Retrieved from https:// www.researchgate.net/ publication/228197588 Creative_Industries_ Aligning_Entrepreneurial_Orientation_and_Innovation_Capacity

41. Prajogo, D. I., \& Ahmed, P. K. (2006). Relationships between innovation stimulus, innovation capacity, and innovation performance. $R \& D$ Management, 36(5), 499-515. https://doi.org/10.1111/j.14679310.2006.00450.x

42. Petty, R., \& Guthrie, J. (2000). Intellectual capital literature review: measurement, reporting and management. Journal of Intellectual Capital, 1(2), 155-176. https://doi. org/10.1108/14691930010348731

43. Pundt, A., Martins, E., \& Nerdinger, F. W. (2010). Innovative behavior and the reciprocal exchange between employees and organizations. German Journal of Human Resource Management, 24(2), 173193. Retrieved from https://www. jstor.org/stable/23279355?seq=1

44. Ramezan, M. (2011). Intellectual capital and organizational organic structure in knowledge society: How are these concepts related? International Journal of Information Management, 31(1), 88-95.

45. Santos-Rodrigues, H., Dorrego, P. F., \& Jardon, C. F. (2010). The influence of human capital on the innovativeness of firms. International Business \& Economics Research Journal, 9(9), 53-63. https://doi.org/10.1016/j. ijinfomgt.2010.10.004

46. Scarborough, N., M., \& Cornwall., J. R. (2015). Enterpreneurship and Effective Small Business Management (11th ed.). England: Pearson Education Limited.

47. Scott, S. G., \& Bruce, R. A. (1994). Determinants of innovative behavior: A path model of individual innovation in the workplace. Academy of Management Journal, 37(3), 580-607. Retrieved from https://www.jstor. org/stable/256701?seq=1

48. Serenko, A., Bontis, N., Booker L., Sadeddin, K., \& Hardie, T. (2010). A scientometric analysis of knowledge management and intellectual capital academic literature (1994-2008). Journal of Knowledge Management, 14(1), 3-23. https://doi. org/10.1108/13673271011015534

49. Sharabati, A. A. A., Naji Jawad, S., \& Bontis, N. (2010). Intellectual capital and business performance in the pharmaceutical sector of Jordan. Management Decision, 48(1), 105-131. https://doi. org/10.1108/00251741011014481

50. Shih, K. H., Chang, C. J., \& Lin, B. (2010). Assessing knowledge creation and intellectual capital in banking industry. Journal of Intellectual Capital, 11(1), 74-89. https://doi. org/10.1108/14691931011013343

51. Sidharta, I., \& Affandi, A. (2016). The empirical study on intellectual capital approach toward financial performance on rural banking sectors in Indonesia. International Journal of Economics and Financial Issues, 6(3), 1247-1253. Retrieved from http://www.econjournals. com/index.php/ijefi/article/ view/2156 
52. Smith, K. G., Collins, C. J., \& Clark, K. D. (2005). Existing knowledge, knowledge creation capability, and the rate of new product introduction in hightechnology firms. Academy of Management Journal, 48(2), 346357. Retrieved from https://www. jstor.org/stable/20159660?seq=1

53. Sullivan, P. H. (2000). Value driven intellectual capital: how to convert intangible corporate assets into market value. John Wiley \& Sons, Inc.

54. Stewart, T. A. (1994). Your company most valuable assetintellectual capital. Fortune, 130(7), 68-74. Retrieved from https:// exhibits.stanford.edu/feigenbaum/ catalog/qd164yd8812

55. Suraj, A. O., \& Bontis, N. (2012) Managing intellectual capital in Nigerian telecommunications companies. Journal of Intellectual Capital, 13(2), 262-282. https://doi. org/10.1108/14691931211225724

56. Sveiby, K. E. (1997). The new organizational wealth: Managing \& measuring knowledge-based assets. Berrett-Koehler Publishers.

57. Sveiby, K. E. (1998). Intellectual capital: Thinking ahead. Australian CPA, 68, 1823. Retrieved from https:// books.google.com.ua/books/ about/Intellectual_capital. html?id=147TnQEACAAJ\&redir $\mathrm{esc}=\mathrm{y}$
58. Swart, J. (2006). Intellectual capital: disentangling an enigmatic concept. Journal of Intellectual capital, 7(2), 136-159. Retrieved from https://researchportal.bath. ac.uk/en/publications/intellectualcapital-disentangling-an-enigmatic-concept

59. Swart, J., \& Kinnie, N. (2010). Organisational learning, knowledge assets and HR practices in professional service firms. Human Resource Management Journal, 20(1), 64-79. https://doi.org/10.1111/j.17488583.2009.00115.x

60. Sydler, R., Haefliger, S., \& Pruksa, R. (2014). Measuring intellectual capital with financial figures: Can we predict firm profitability? European Management Journal, 32(2), 244-259. https://doi. org/10.1016/j.emj.2013.01.008

61. Ulrich, D. (1998). Intellectual capital = competence $\mathrm{x}$ commitment. MIT Sloan Management Review, 39(2), 15-26. Retrieved from https:// sloanreview.mit.edu/article/ intellectual-capital-competence- $\mathrm{X}$ commitment/

62. Wang, D., \& Chen, S. (2013). Does intellectual capital matter? Highperformance work systems and bilateral innovative capabilities. International Journal of Manpower 34(8), 861-879. https://doi. org/10.1108/IJM-07-2013-0167
63. Youndt, M. A., Subramaniam, M., \& Snell, S. A. (2004). Intellectual capital profiles: An examination of investments and returns. Journal of Management Studies, 41(2), 335-361. https://doi.org/10.1111/ j.1467-6486.2004.00435.x

64. Yu, C., Yu, T. F., \& Yu, C. C. (2013). Knowledge sharing, organizational climate, and innovative behavior: A cross-level analysis of effects. Social Behavior and Personality: an International Journal, 41(1), 143-156. Retrieved from https:// www.researchgate.net/deref/ http\%3A\%2F\%2Fdx.doi.org\%2F1 0.2224\%2Fsbp.2013.41.1.143

65. Wu, W. Y., Chang, M. L., \& Chen, C. W. (2008). Promoting innovation through the accumulation of intellectual capital, social capital, and entrepreneurial orientation. RઐD Management, 38(3), 265-277. https://doi. org/10.1111/1467-9914.00120-i1

66. Wu, S. H., Lin, L. Y., \& Hsu, M. Y. (2007). Intellectual capital, dynamic capabilities and innovative performance of organisations. International Journal of Technology Management, 39(3-4), 279-296. Retrieved from https://www.researchgate.net/ publication/247832522_Intellectual_Capital_Dynamic_Capabilities_and_Innovative_Performance_of_Organisations 